\title{
Published works of Alfred North Whitehead
}

188610 February. 'A celebrity at home. The clerk of the weather'. Cambridge Review, vol. 7, pp. 202-3.

188612 May. 'Davy Jones'. Cambridge Review, vol. 7, pp. 311-12.

18886 March. 'A visitation'. Cambridge Fortnightly, vol. 1(4), pp. 81-3.

1888 'On the motion of viscous incompressible fluids: a method of approximation'. Quarterly Journal of Pure and Applied Mathematics, vol. 23, pp. 78-93.

1888 'Second approximations to viscous fluid motion. A sphere moving steadily in a straight line'. Quarterly Journal of Pure and Applied Mathematics, vol. 23, pp. 143-52.

189120 February. 'The Fens as seen from skates'. Cambridge Review, vol. 12 (attribution to Whitehead not wholly certain).

189614 May. 'On ideals: with reference to the controversy concerning the admission of women to degrees in the University'. Cambridge Review, vol. 17, pp. 310-11.

189810 March. 'The geodesic geometry of surfaces in non-Euclidean space'. Proceedings of the London Mathematical Society, vol. 29, pp. 275-324.

1898 A Treatise on Universal Algebra. Cambridge University Press Warehouse.

18992 February. 'Sets of operations in relation to groups of finite order'. Proceedings of the Royal Society of London, vol. 64, pp. 319-20.

1901 April. 'Memoir on the algebra of symbolic logic'. American Journal of Mathematics, vol. 23(2), pp. 139-65.

1901 October. 'Memoir on the algebra of symbolic logic, part II'. American Journal of Mathematics, vol. 23(4), pp. 297-316.

1902 'On cardinal numbers'. American Journal of Mathematics, vol. 24, pp. 367-94.

1903 'The logic of relations, logical substitution groups, and cardinal numbers'. American Journal of Mathematics, vol. 25, pp. 157-78.

190314 May. 'The University library'. Cambridge Review, vol. 24, p. 295.

1904 'Theorems on cardinal numbers'. American Journal of Mathematics, vol. 26, pp. 31-2.

1905 'Note'. Revue de Metaphysique et de Morale, vol. 13, pp. 916-17.

190629 March. 'On mathematical concepts of the material world'. Philosophical Transactions of the Royal Society of London, vol. 77(517), pp. 290-1.

1906 Through to 1910. The Axioms of Projective Geometry. Cambridge University Press Warehouse.

19065 November. 'Liberty and the enfranchisement of women'. Cambridge Women's Suffrage Association, pamphlet.

1907 March. The Axioms of Descriptive Geometry. Cambridge University Press Warehouse.

1910 (With Bertrand Russell) 'Non-Euclidean geometry'. Encyclopedia Britannica (11th edition), vol. 11, pp. 724-30. 
1910 'Axioms of geometry'. Encyclopedia Britannica (11th edition), vol. 11, pp. 730-6.

1910 October. 'The philosophy of mathematics'. Science Progress in the Twentieth Century, vol. 5, pp. 234-9.

1910 December (with Bertrand Russell) Principia Mathematica, Volume 1. Cambridge University Press.

1911 An Introduction to Mathematics. Williams and Norgate, Henry Holt.

1912 'The place of mathematics in a liberal education'. Journal of the Association of Teachers of Mathematics for the Southeastern Part of England, vol. 1(1).

1912 (With Bertrand Russell) Principia Mathematica, Volume 2. Cambridge University Press.

1913 (With Bertrand Russell) Principia Mathematica, Volume 3. Cambridge University Press.

1913 'The principles of mathematics in relation to elementary teaching'. Proceedings of the Fifth International Congress of Mathematicians, vol. 2, pp. 449-54. Also published in L'Enseignment Mathematique.

1913 March. 'Presidential address to the London branch of the Mathematical Association'. Mathematical Gazette, vol. 7, pp. 87-94.

1914 'Report of the Council of the Royal Society of London'. Year-Book of the Royal Society, pp. 177-87.

1915 'Report of the Council of the Royal Society of London'. Year-Book of the Royal Society, pp. 176-85.

1916 January. 'The Aims of education: a plea for reform'. Mathematical Gazette, vol. 8, pp. 191-203.

1916 'Space, time, and relativity'. Proceedings of the Aristotelian Society, vol. 16, pp. $104-29$.

1916 'The organisation of thought'. Report of the 86th Meeting of the British Association for the Advancement of Science, pp. 355-65. Also published with slight differences in Proceedings of the Aristotelian Society, vol. 17, pp. 58-76.

1916 'La théorie relationniste de l'espace'. Revue de Métaphysique et de la Morale, vol. 23, pp. 423-54.

1917 The Organisation of Thought. Williams and Norgate, Greenwood Press.

1917 March. 'Technical education and its relation to science and literature'. Mathematical Gazette, vol. 9(128), pp. 20-33. Also published in Technical Journal vol. 10 (January), pp. 59-74.

1917 (With A. W. Siddons) 'Letter to the Editor'. Mathematical Gazette, vol. 9, p. 14.

1918 'Graphical solution for high-angle fire'. Proceedings of the Royal Society, Series A 94, pp. 301-7.

1919 'Fundamental principles of education'. Report of the 87th Meeting of the British Association for the Advancement of Science, p. 361.

1919 (With Oliver Lodge, J. W. Nicholson, Henry Head, Adrian Stephen and H. Wildon Carr) 'Symposium: time, space and material: are they, and if so in what sense, the ultimate data of science?' Proceedings of the Aristotelian Society, Supplementary Volumes, vol. 2, 'Problems of Science and Philosophy', pp. 44-108. 
1919 An Enquiry Concerning the Principles of Natural Knowledge. Cambridge University Press.

191915 November. 'A revolution in science'. The Nation, vol. 26, pp. 232-3.

1919 'Address on founder's day [Stanley Technical Trade School, South Norwood, London]'. Coventry and Son.

1920 The Concept of Nature. Cambridge University Press.

192012 February. 'Einstein's theory: an alternative suggestion'. Times Educational Supplement.

1921 'Science in general education'. Second Congress of the Universities of the Empire, pp. 31-9.

1921 (With many others) Report of the Committee Appointed by the Prime Minister to Inquire into the Position of Classics in the Educational System of the United Kingdom. His Majesty's Stationary Office.

192220 February. (With H. W. Carr, T. P. Nunn and Dorothy Wrinch) 'Discussion: the idealistic interpretation of Einstein's theory'. Proceedings of the Aristotelian Society, New Series, vol. 22, pp. 123-38.

192218 April. 'Some principles of physical science', presentation at Bryn Mawr College conference put in print as a booklet and also published later that year as a chapter in The Principle of Relativity.

192216 July. 'The philosophical aspects of the principle of relativity'. Proceedings of the Aristotelian Society New Series, vol. 22, pp. 215-23.

1922 The Principle of Relativity, with Applications to Physical Science. Cambridge University Press.

1922 November. 'The rhythm of education'. Bulletin of the American Association of University Professors, vol. 9(7), pp. 17-19.

19226 November. 'Uniformity and contingency: the presidential address'. Proceedings of the Aristotelian Society New Series, vol. 23, pp. 1-18.

1923 (With H. W. Carr and R. A. Sampson ) 'Symposium. The problem of simultaneity: is there a paradox in the principle of relativity in regard to the relation of time measured and time lived?' Aristotelian Society, Supplementary 3, 'Relativity, Logic and Mysticism', pp. 15-41.

1923 'The place of classics in education'. Hibbert Journal, vol. 21, pp. 248-61.

1923 'The rhythmic claims of freedom and discipline'. Hibbert Journal, vol. 21, pp. 657-68.

1923 'The first physical synthesis'. In Science and Civilization, pp. 161-78. Oxford University Press.

192317 February. 'Letter to the Editor: Reply to review of The Principle of Relativity'. New Statesman.

1925 August. 'Religion and science'. Atlantic Monthly, vol. 136, pp. 200-7.

1925 'The importance of friendly relations between England and the United States'. Phillips Bulletin, vol. 19, pp. 15-18.

1925 October. Science and the Modern World. Macmillan.

1926 September. Religion in the Making. Macmillan and Cambridge University Press.

1926 'Principia Mathematica: to the Editor of Mind'. Mind, vol. 35(137), p. 130.

1926 Autumn. 'The education of an Englishman'. Atlantic Monthly, vol. 138, pp. 192-8. 
1927 'England and the narrow seas'. Atlantic Monthly, vol. 139, pp. 791-8.

1927 'Time'. In Sixth International Congress of Philosophy, pp. 59-64. Longmans, Green \& Co.

1927 November. Symbolism: Its Meaning and Effect. Macmillan.

1928 'Universities and their function'. Atlantic Monthly, vol. 141, pp. 638-44.

1929 Process and Reality. Macmillan and Cambridge University Press.

1929 The Aims of Education and Other Essays. Macmillan, Williams \& Norgate.

1929 The Function of Reason. Princeton University Press.

1930 January. 'An address delivered at the celebration of the fiftieth anniversary of the founding of Radcliffe College'. Radcliffe Quarterly, vol. 14, pp. 1-5.

1930 'Prefatory note'. In Susanne K. Langer, The Practice of Philosophy, p. vii. Henry Holt \& Co.

1931 'On foresight'. Introduction, in Wallace Brett Donham, Business Adrift, pp. xi-xxix. McGraw-Hill.

1931 'Objects and subjects'. Proceedings and Addresses of the American Philosophical Association, vol. 5, pp. 130-46.

1932 'Symposium in honor of the seventieth birthday of Alfred North Whitehead', speech included in a booklet of symposium proceedings printed by Harvard University Press (pp. 22-9).

1933 Adventures of Ideas. Macmillan and Cambridge University Press.

1933 'The study of the past - its uses and its dangers'. Harvard Business Review, vol. 11(4), pp. 436-44.

1934 'Foreword'. In The Farther Shore: An Anthology of World Opinion on the Immortality of the Soul. Houghton Mifflin.

1934 Nature and Life. University of Chicago Press. (This book, which comprises two essays, was republished in its entirety as Part 3 of Modes of Thought, 1938.)

1934 'Philosophy of life'. In Dagobert D. Runes (ed.), Twentieth Century Philosophy: Living Schools of Thought, pp. 131-44. Philosophical Library.

1934 'Foreword'. In Willard van Orman Quine, A System of Logistic, pp. ix-x. Harvard University Press.

1934 July. 'Indication, classes, numbers, validation'. Mind, New Series, vol. 43(171), pp. 281-97.

1934 October. 'Corrigenda. Indication, classes, numbers, validation'. Mind, New Series, vol. 43(172), p. 543.

1935 'Minute on the life and services of Professor James Haughton Woods'. Harvard University Gazette, vol. 30, pp. 153-5.

1935 'The aim of philosophy'. Harvard Alumni Bulletin, vol. 38, pp. 234-5.

1935 'Eulogy of Bernard Bosanquet'. In Bernard Bosanquet and His Friends: Letters Illustrating the Sources and the Development of His Philosophical Opinions, p. 316. George Allen \& Unwin.

1936 'Memories'. Atlantic Monthly, vol. 157, pp. 672-9.

1936 'Harvard: the future'. Atlantic Monthly, vol. 159, pp. 260-70.

1937 'Remarks'. Philosophical Review, vol. 46, pp. 178-86.

1938 Modes of Thought. Macmillan and Cambridge University Press.

1939 'An appeal to sanity'. Atlantic Monthly, vol. 163, pp. 309-20. 
1939 'John Dewey and his influence'. In Paul Arthur Schilpp (ed.), The Philosophy of John Dewey, pp. 477-9. Northwestern University Press.

1940 'Aspects of freedom'. In Ruth Nanda Anshen (ed.), Freedom: Its Meaning, pp. 42-67. Harcourt, Brace.

1940 'The issue: freedom'. Boston Daily Globe, 24 December.

1941 'Autobiographical notes'. In Paul Arthur Schilpp (ed.), pp. 1-15. The Philosophy of Alfred North Whitehead. Northwestern University Press.

1941 'Mathematics and the good'. In Paul Arthur Schilpp (ed.), The Philosophy of Alfred North Whitehead, pp. 666-81. Northwestern University Press.

1941 'Immortality'. In Paul Arthur Schilpp (ed.), The Philosophy of Alfred North Whitehead, pp. 682-700. Northwestern University Press.

1942 February. 'The problem of reconstruction'. Atlantic Monthly, vol. 169, pp. 172-5.

1945 Preface to 'The organization of a story and a tale', by William Morgan. Journal of American Folklore, vol. 58(229), p. 169.

1942 October. 'Statesmanship and specialized learning'. Proceedings of the American Academy of Arts and Sciences, vol. 75(1), pp. 1-5.

1948 Essays in Science and Philosophy. Philosophical Library. 